\title{
COMPLIANCE WITH ICHTHYOFAUNAL DIVERSITY CONSERVATION MEASURES IN LAKE LANAO, LANAO DEL SUR PROVINCE (PHILIPPINES)
}

\author{
Misael Mohamad SANGUILA * and Carmelita Garcia HANSEL ** \\ * Mindanao State University, College of Fisheries, Fisheries Drive 001, Marawi City, Philippines, \\ PH-9700, msanguila@gmail.com \\ ** Mindanao State University, College of Natural Sciences and Mathematics, Antonio Isidro Avenue \\ 004, Marawi City, Philippines, PH-9700, carmelita_hansel@yahoo.com
}

DOI: 10.1515/trser-2015-0072

KEYWORDS: Conservation measures, fisheries management, fisheries resources.

\section{ABSTRACT}

This study was conducted to probe the effectiveness of, and compliance with, legislated fish diversity conservation measures in lake Lanao employing structured interview techniques. Results showed respondents' age from 19 to 70.

Most of the respondents are educated, having taken vocational courses, with a general weekly income of PhP 2,000-2,499 (\$42.92-\$53.62). The respondents are knowledgeable of the fisheries laws, ranging from $39.29 \%$ to $76.43 \%$ whilst their compliance is high, ranging from $81.31 \%$ to $100 \%$.

RESUMEN: Cumplimiento de las Medidas de Conservación de Diversidad de la Ictiofauna en el Lago Lanao, Provincia de lanao Del Sur (Filipinas).

Este estudio se realizó con el objetivo de estudiar la eficacia y el cumplimiento de las medidas de conservación de la diversidad de peces legislados en el Lago Lanao empleando la técnica de entrevista estructurada. Los resultados muestran que la edad de hijos encuestados oscila entre 19-70.

La mayoría de los encuestados están escolarizados, habiendo tomado cursos de formación profesional, con un ingreso semanal general de PhP 2,000-2,499 (\$42.92-\$53.62). Los encuestados tienen conocimiento de las leyes de pesca, que van desde $39.29 \%$ al $76.43 \%$, mientras que su cumplimiento es alto, desde $81.31 \%$ a $100 \%$.

REZUMAT: Respectarea măsurilor de conservare a diversității ihtiologice din Lacul Lanao, Provincia Lanao del Sur (Filipine).

Acest studiu a fost inițiat pentru a testa efectivitatea și respectarea legislației privind măsurile de conservare a diversității ihtiologice din lacul Lanao aplicând tehnica interviului structurat. Vârsta respondenților variază între 19 și 70 ani.

Majoritatea subiecților sunt educați, având cursuri de vocație, cu venituri săptămânale cuprinse între 2.000-2.499 $\mathrm{PhP}(\$ 42.92-\$ 53)$.

2). Numărul respondenților care au cunoștințe privind legislația de pescuit se încadrează între $39,29 \%$ și $76,43 \%$ în timp ce numărul celor care respectă legea este mare încadrându-se între valorile $81,31 \%$ și $100 \%$. 


\section{INTRODUCTION}

The Philippines, being an archipelagic country, has an abundance of marine resources that play an important role in the nation's economy. In addition, it possesses a number of inland water bodies that contribute further to its fishery resources. It is therefore appropriate that there is an institutional framework, with policies and legislation, rules and regulations, and ordinances both at the national and at the local level, to protect these resources so as to ensure their sustainability, because the economy and the local population are dependent on them. A vital component in ensuring the successful management and conservation of the country's aquatic resources, especially inland resources, is the fisher folks, fisher folks' knowledge and awareness of these laws, and most essentially, their compliance with the laws.

In 1998, the Philippine Congress enacted into law Republic Act 8550, also called the Philippine Fisheries Code. It is an extensive piece of legislation for the development, management and conservation of the Philippines' aquatic resources, and incorporates all appropriate laws. Chapter VI of the Code provides for certain prohibitions (and corresponding penalties) in fishery and the use of fishery techniques that have negative effects on aquatic resources.

Studies on compliance with fisheries laws in the Philippines have been conducted prior to and after the enactment of the Fisheries Code. Most of these researches were undertaken in marine environments. Palma (2006), in her study on the suitableness of the Philippine policy, legal, and institutional framework to combat illegal, unregulated, and unreported (IUU) fishery, concluded that they are inadequate to address IUU fishing based on criteria established in the international fisheries instruments. In their work conducted in San Salvador Island, Katon et al. (1999) discussed how the fisher community and the local government rose above the obstacles associated with a de facto open-access fishery by highlighting the creation, management and impact on ecosystem health, both natural and human, of a marine reserve and sanctuary. Capistrano (2010) examined the impact of local and national policies such as property rights on the participation of indigenous peoples, specifically the Tagbanua of the Philippines in relation to fisheries management. Dalabajan (2005) examined the socioeconomic context and the legal and political milieu in which the problems around cyanide fishing are carried out. Adan (2009) examined the public policies on fisheries as contained in national and local legislations and how they are transformed into management actions at the local government level in Panguil Bay, concluding that intervention programs to build capacity for local government units to curb illegal and destructive exploitation of Panguil Bay had hardly any impact on the problem. Other studies conducted on implementation and compliance with fisheries policies includes those of Espectato and Serofia (2014), Fabinyi (2007), McClellan (2010), Napata et al. (2014) and Knudsen (2012). No studies on this topic have previously been conducted on lake Lanao.

For the present study, provisions in the Fisheries Code which would guarantee sustainable fish biodiversity in lake Lanao were probed as to the compliance and effectiveness of their implementation. 


\section{These statutes with the corresponding penalties}

A. Section 88. Fishing Through Explosives, Noxious or Poisonous Substance, and/or Electricity which specifically stipulate that:

1. It shall be unlawful for any human being to catch, take or collect, fish or any fishery species in Philippine waters with the use of electric energy, explosives that blows up, toxic or harmful substances in the Philippine fishery areas, which will asphyxiate, harm, stupefy, mutilate or render senseless aquatic species: Provided, that the Department, subject to such conditions regard mandatory and endorsement from the concerned LGUs, may allow, for study, scientific and/or educational aims, the use of electric energy, toxic or harmful substances to catch, or gather aquatic species: Provided, further, that the use of toxic or harmful substances to eliminate predators in bodies of water in conformity with authorized scientific procedures and without inducing negative impact in waters and grounds shall not be defined as prohibited fishing. It will be against the law for any entity to have, trade, or dispose of, any fish or fishery species which have been illegally captured, or collected. The finding of any explosives and/or chemical substances which include able to be exploded elements, or toxic or harmful substances, or gears or devices for electrofishing in any vessel or in the possession of any fisher folk, operator, fishing boat official or fish worker shall constitute prima facie proof, that was used for fishing in breaking of this Code. The finding in any vessel of fish captured or killed with the use of toxic or harmful substances, by electric energy, or by explosive, shall represent prima facie proof that the fisher folk, operator, boat official or fish worker is fishing with the use thereof; 2. Mere ownership of toxic or harmful substances, electrofishing devices or explosives, for fishing shall be culpable by imprisonment between six (6) months to two (2) years; 3. The use of toxic or harmful substances, electrofishing devices, or explosives, for fishing shall be culpable by imprisonment ranging from five (5) years to ten (10) years without prejudice to the filing of separate criminal cases when the use of the same result to physical injury or loss of human life; 4. Trading, or in any manner deal with, for income, capture fisheries species shall be culpable by imprisonment ranging from six (6) months to two (2) years. The toxic or harmful substances, electrical devices, and/or explosives, as well as the vessels, fishing gears and catch shall be forfeited.

B. Section 89. Use of Fine Mesh Net.

It shall be against the law to fishing using nets with mesh smaller than that with which may be fixed by the Department: Provided, that the forbiddance on the use of fine mesh net shall not apply to the collecting of fry, elvers, glass eels, tabios, and species which by their nature are small but adult to be recognized in the enforce rules and supervision by the Department. Abuse of the subject the offender to a fine from Two thousand pesos (P2,000.00) to Twenty thousand pesos (P20,000.00) or detention from six (6) months to two (2) years or both such fine and imprisonment at the judgment of the court: Provided, that if the offense is committed by a commercial fishing vessel, the ship captain and the master fisherman shall also be under the punishment provided herein: Provided, that the person who has possession of/one who operates the commercial fishing vessel who contravene this provision shall be subjected to the same punishment provided herein: Provided, that the Department is authorized to demand upon the offender an administrative fine and/or cancel his above shall authorization or certificate or both. 
C. Section 97. Fishing or Taking of Rare, Threatened or Endangered Species.

It shall be against the law to fish or take rare, threatened or endangered species as recorded in the CITES and as determined by threatened or the Department. Breaking of the provision of this section shall be penalized by forcible detention of twelve (12) years to twenty (20) years and/or fine of one hundred and twenty thousand pesos (P120,000.00) and forfeiture of the catch and the revocation of fishing license.

D. Section 98. Capture of Sabalo and Other Breeders/Spawners.

It is illegal for any entity to catch, gather, capture or possess mature milkfish or sabalo and such other breeders or spawners of other fishery species as may be determined by the Department: Provided, that catching of sabalo and other breeders/spawners for local breeding intention or scientific or study meanings may be admitted subject to guidelines to be make known by the Department. Breaking of the provision of this section shall be penalized by imprisonment of six (6) months and one (1) day to eight (8) years and/or a fine of Eighty thousand pesos (P80,000.00) and forfeiture of the capture, and fishing gears used and cancellation of authorization.

E. Section 102.

Aquatic Pollution. Aquatic pollution, as defined in this Code shall be illegal. Breaking of the provision in this section shall be penalized by imprisonment of six (6) years and one (1) day to twelve (12) years and/or a fine of eighty thousand pesos (P80,000.00) and an additional fine of eight thousand pesos (P8,000.00) per day until such abuse ceases and the fines are compensated.

The present study investigated whether the local population, the fisher folks in particular, are knowledgeable of and abide to the stated conservation measures. The results will support planners and policy makers in the Province of Lanao del Sur in their formulation of more acceptable and effective strategies for fisheries conservation. Moreover, this study will provide feedback on the effectiveness and adequacies of the fisheries conservation laws implemented in the province, leading to their re-evaluation for the improvement of the Province' fishing industry and community economic benefit. Finally, the findings of the present study provide useful data for the formulation of more relevant fishery resource conservation policy at the local, regional, and to a broader extent, at the national level.

\section{MATERIAL AND METHODS \\ Location of the study}

Lake Lanao is located in the province of Lanao del Sur, Mindanao Island, in the southern Philippines, north of the equator with coordinates $8^{0} 0^{\prime} \mathrm{N}, 123^{0} 5^{\prime} \mathrm{E}$ (Figs. 1 and 2). Frey (1969) summarizes several morphometric data of the lake as follows: area $-357 \mathrm{~km}^{2}$; volume - $21.5 \mathrm{~km}^{3}$; maximum depth - $112 \mathrm{~m}$; mean depth (volume/area) - $60.3 \mathrm{~m}$; and replacement time (volume/mean annual discharge) -6.5 years.

Surrounding the lake are 17 municipalities and one city (Marawi City) of Lanao del Sur inhabited by the Muslim ethno linguistic group, the Meranaos ("people of the lake"). The lake is of great importance to them as a fishery and aquatic resource, as a transport route, as water source for domestic use (both for the household and for religious ablution), and also for waste disposal. Regionally, the lake is important to the island of Mindanao as a source of hydropower generation through a series of hydropower plants starting at the lakeshore near the mouth of the Agus River (the sole outlet of lake Lanao) and along the Agus River itself which provides around $65 \%$ of the energy requirements of Mindanao. 


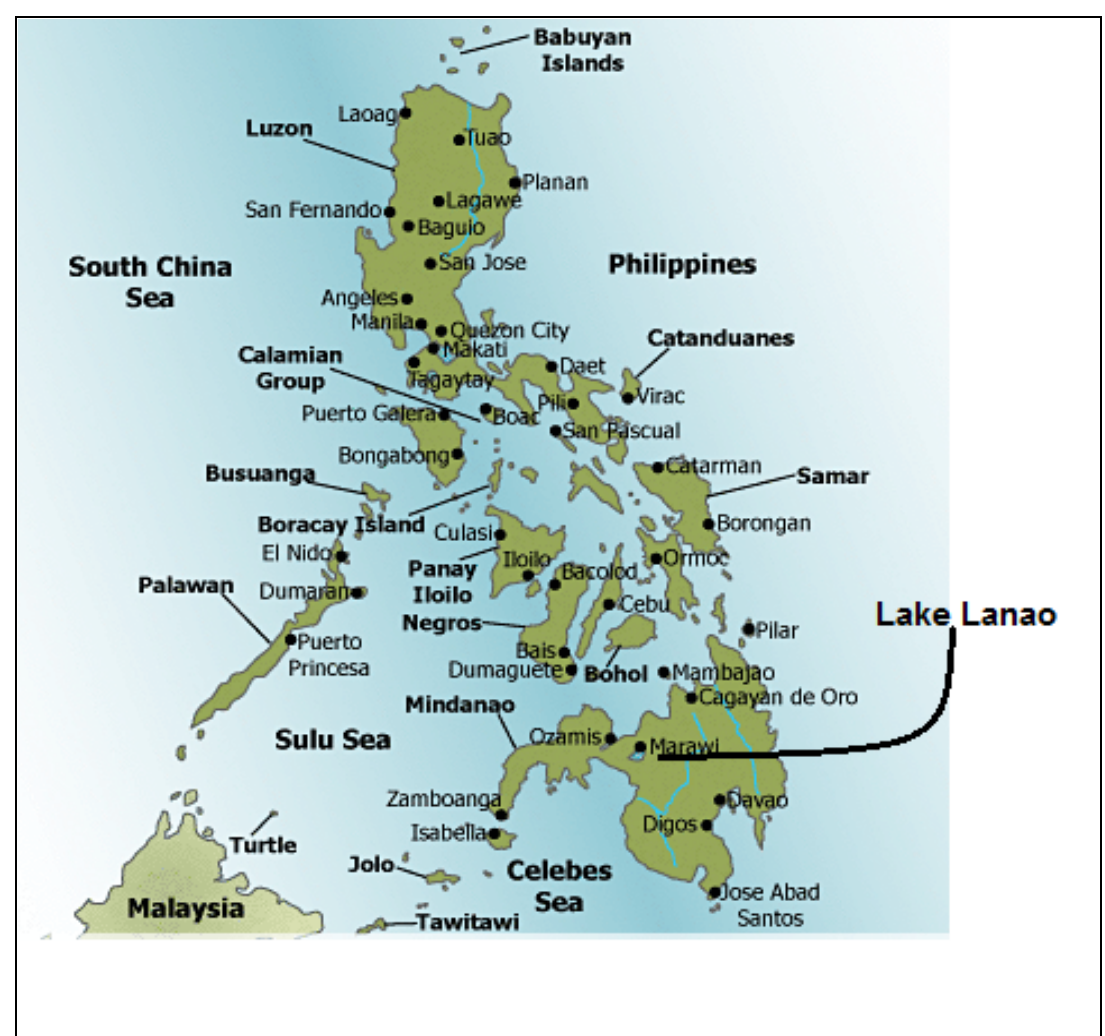

Figure 1a: Mindanao Island and Lanao Lake in Philippines (Google Map, 2015).

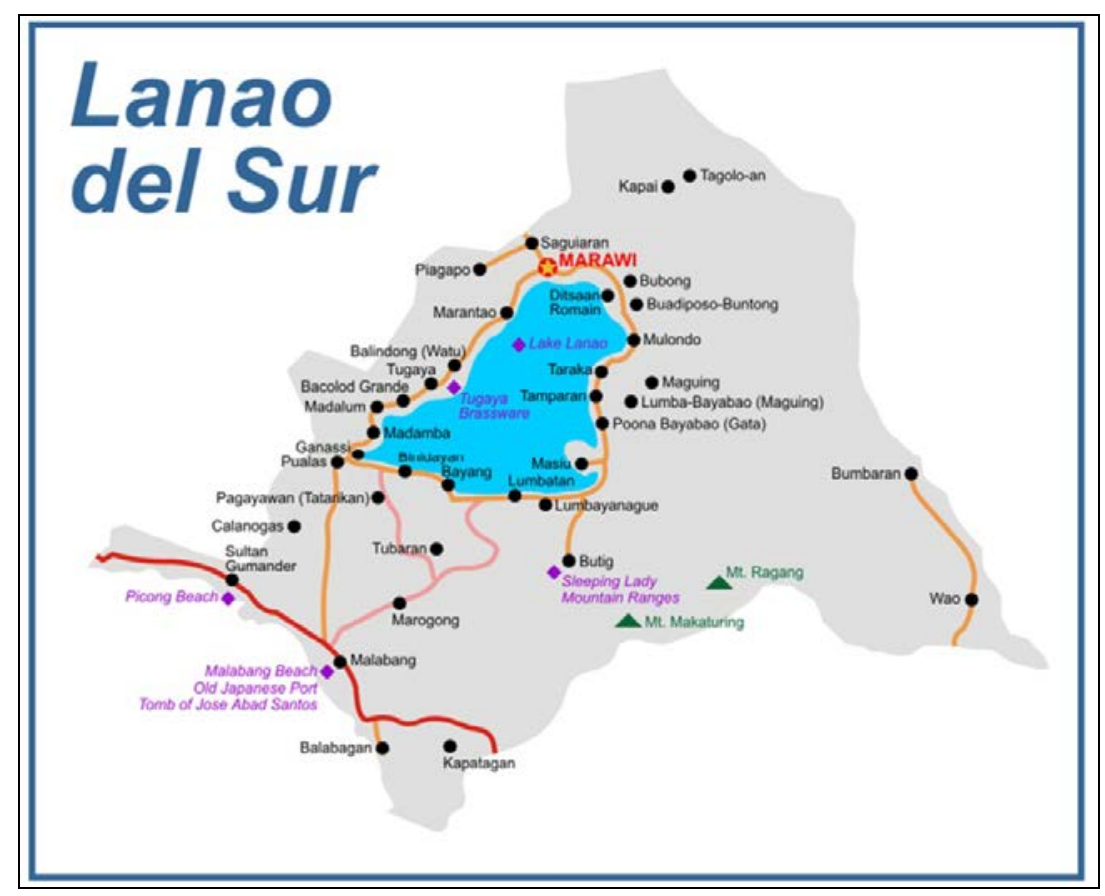

Figure 1b: Lanao Lake and the Province of Lanao del Sur (Source: "Interagency meeting to discuss Lanao Lake watershed management set” accessed at https://tigbalita.wordpress.com/). 


\section{Sampling Procedure}

The respondents of the present descriptive-evaluative research were registered fisher folks of the Fishermen Association from three lakeshore municipalities of Lanao del Sur (Masiu, Madalum, and Bacolod). Fifty percent (50\%) of the total number of registered fisher folks in each municipality were opportunistically selected and had the structured interview administered. A total of 140 fisher folks were surveyed in the study. The structured survey covered the respondents' socio-economic profile, their knowledge, and compliance with the ichthyofauna conservation measures, and additionally included information on the fish species caught, fishing gear used, and the fishing activities at the site. During the conduct of the interview, formal and informal conversation was undertaken using the local vernacular. Only those respondents who were knowledgeable of the ichthyofauna conservation measures were asked about their adherence to the stated legislative protection measures. This is based on the assumption that those who do not have knowledge of the laws cannot be expected to have a reasonable evaluation of such statutes. Prior to the administration of the interview, a pre-test was conducted on 20 respondents (not part of the survey sample) amongst fisher folks in Kauswagan Lanao del Norte, situated 50 kilometers from Marawi Ctiy. This is to weed out ambiguous questions and statements in the questionnaire and to check its validity.

A survey on the collection of fish samples was conducted at various landing sites in each sampled municipality, from December 2014 to May 2015, in the early morning, a period when fishermen and fish landing areas are very active. The purchased samples from fishermen were photographed and identification was carried out using Fishbase (2015).

\section{Data Analysis}

The data collected in the study was analyzed using Systat version 13.0 (2005) and discussed using the following statistical tools:

a. Descriptive statistics in discussing the socio-economic-demographic profile of the respondents, their knowledge, and their obedience to the ichthyofauna conservation measures which include: 1 . Measures of central tendency such as frequency distribution and mean which would yield the average of the obtained data; 2. Percentage Analysis in treating data on respondents' socio-economic-demographic characteristic, knowledge and obedience to the posed laws; 3. Measures of Dispersion (scatter or spread) which indicate the extent to which the observations tend to spread-out. This include the maximum-minimum range which is the simplest dispersion measure, standard deviation which considers not only extreme observed values but all observations thereby giving more accurate description of the observation; and coefficient of variation which depicts the size of a standard deviation relative to the mean.

b. Multiple Linear Regression in determining the relationship of the respondents' socio-economic characteristics with their knowledge and their obedience towards the ichthyofauna diversity conservation measures. The $H_{o}$ states that there is no relationship between the respondents' socio-economic characteristics and their knowledge and obedience to the ichthyofauna conservation measures. The significance level was set at 0.05.

\section{RESULTS AND DISCUSSION}

The descriptive statistics of the respondents are presented (Tab. 1, Figs. 2-5). As shown in the table, the youngest respondent in the study was aged 19 and the oldest was ages 70 years old. The number of dependent children ranged from one to a maximum of eight. In the case of their educational attainment, most of the respondents were educated, having taken vocational courses, and had a general weekly income of PhP 2,000-2,499 (\$42.92-\$53.62). 
Table 1: Descriptive statistics of the respondents.

\begin{tabular}{|r|c|c|c|c|}
\hline \multicolumn{1}{|c|}{ Socio-Economic Profile } & $\mathrm{N}$ & Mean & $\begin{array}{c}\text { Range } \\
\text { (min-max) }\end{array}$ & $\begin{array}{c}\text { Coefficient of } \\
\text { variation }\end{array}$ \\
\hline Age & 140 & $38.6 \pm 9.77$ & $19.00-70.00$ & 0.254 \\
\hline Number of dependent children & 140 & $4.16 \pm 1.5$ & $1.00-8.00$ & 0.39 \\
\hline Educational Attainment & 140 & $4.17 \pm 1.00$ & $2.00-6.00$ & 0.24 \\
\hline Weekly Income & 140 & $5.15 \pm 0.95$ & $2.00-6.00$ & 0.19 \\
\hline
\end{tabular}

Table 2 reflects the knowledge and obedience of the respondents to the various ichthyofauna conservation measures employed in the study. This result is graphically presented in figures 6 and 7. Majority of the respondents are knowledgeable of the fisheries laws, ranging from $39.29 \%$ (sec. 102) to $76.43 \%$ (sec. eight). As previously stated, only those who were knowledgeable of the fisheries laws were asked with regard to their obedience thereto. The obedience of the respondents to the fisheries laws is high, ranging from $81.31 \%$ to $100 \%$. The relationship between the respondents' socio-economic characteristics and their knowledge of ichthyofauna conservation measures is presented in table 4 . There is a relationship between the respondents' ages $(p<0.05)$ and number of children $(p<0.05)$ with their knowledge of the posed fisheries laws. As the respondents get older, there is an increase of their knowledge on the illegality of gathering fish with the use of electricity, explosives, and noxious or poisonous substance. This is attributed to the fact that as the fisher gets older, he would accumulate more knowledge and elucidations that fishing using electricity, poisonous substances, and explosive is dangerous. There is an inverse relationship between the respondents' number of children and others. The greater the number of children the respondents has, the less knowledgeable they are of the illegality of gathering fishes with the use of electricity, explosives, and noxious or poisonous substance. This may imply that those having more children have a lack of community awareness, such as the importance of family planning, that is transferred over to their lack of awareness and knowledge of fisheries conservation laws. The rest of the respondents' socio-economic characteristics do not have any relationship with their knowledge of the stated fisheries statutes. The proportion of influence of socio-economic factors to the respondents' knowledge is low, ranging from $1.0 \%$ (sec. 89) to $34.40 \%$ (sec. 88). The remaining, large, proportion is inferred to be contributed by non-socio-economic factors such as societal mores, religious beliefs, and other such cultural factors. In the course of interviews and conversations with the respondents, almost all of them disclosed that their understandings of the posed laws were based on their rigid Islamic indoctrination. Respondents specifically mentioned the following Qur'anic verses as providing the base of their knowledge: Qur'an 16:14, Qur'an 5:96, Qur'an 18:61-63, Quran 2:205, amongst others. This observation is supported by Jamil (1999) and Abubakar (2015) who both identified that in Islam, all human beings are ordered to conserve water. Abu Hurayrah reported that the Prophet said: "Avoid urinating into still water (in a reservoir or pond, i.e. water that does not flow), and then bathing with it”. 


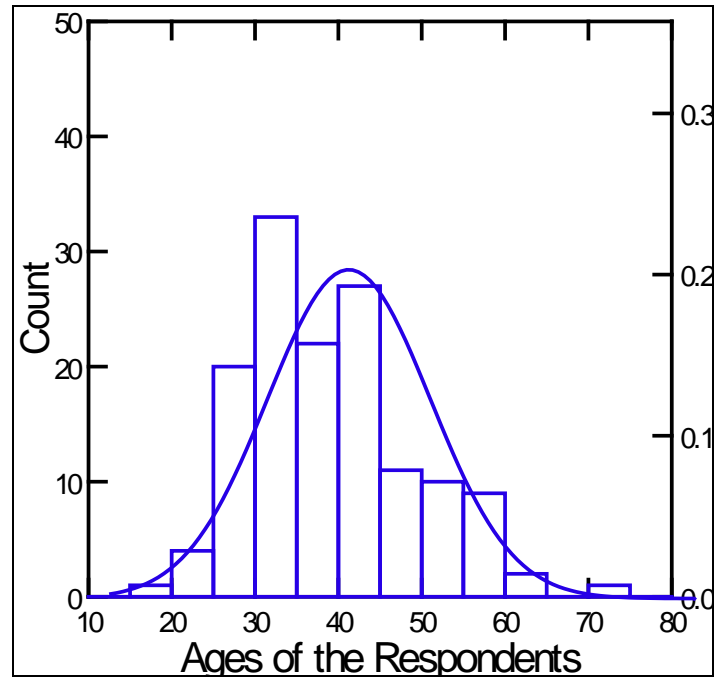

Figure 2: Respondents' ages.

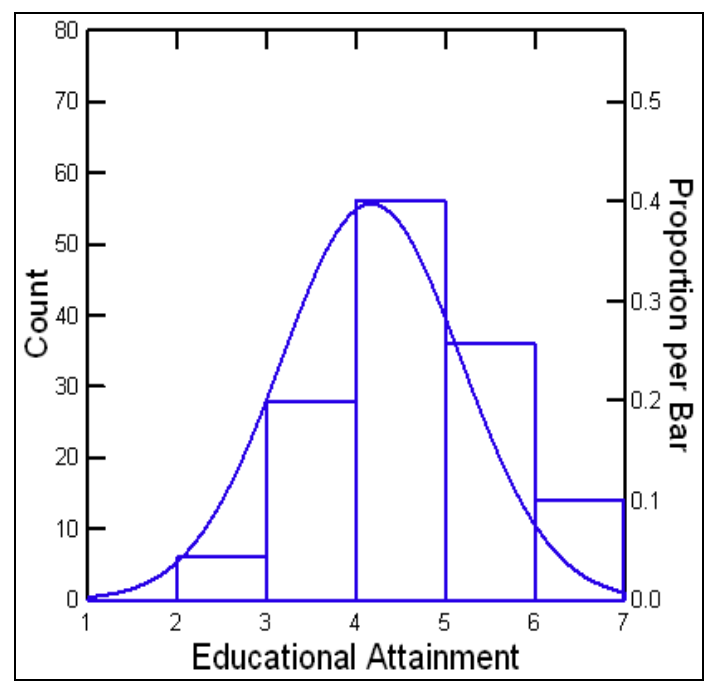

Figure 4: Respondents' educational attainment.

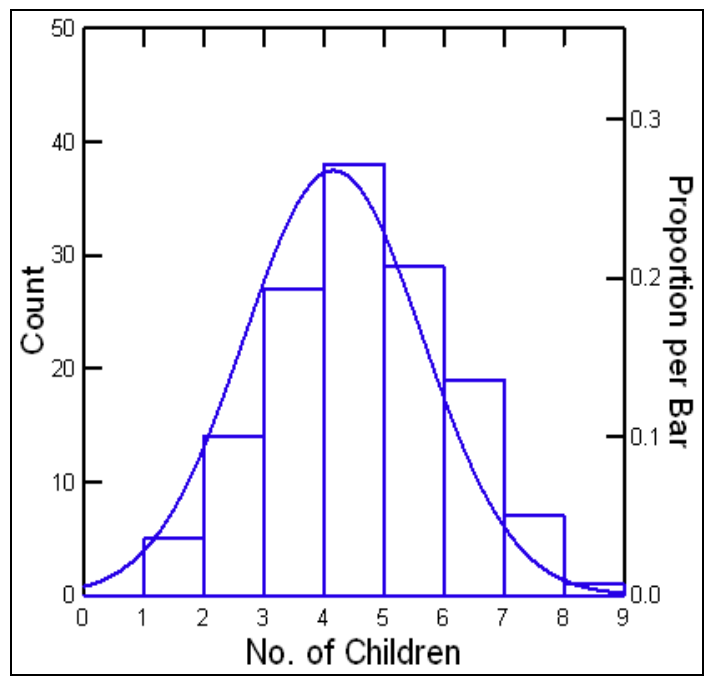

Figure 3: Respondents' number of children.

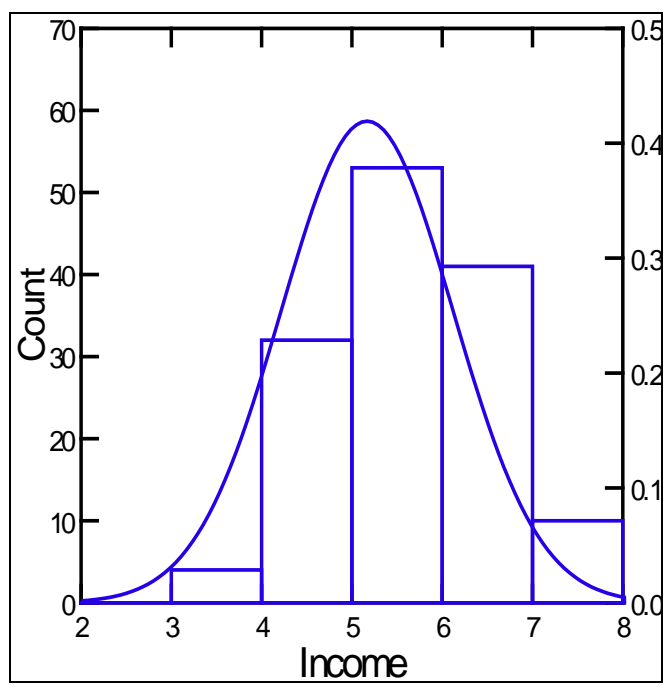

Figure 5: Respondents' income. 


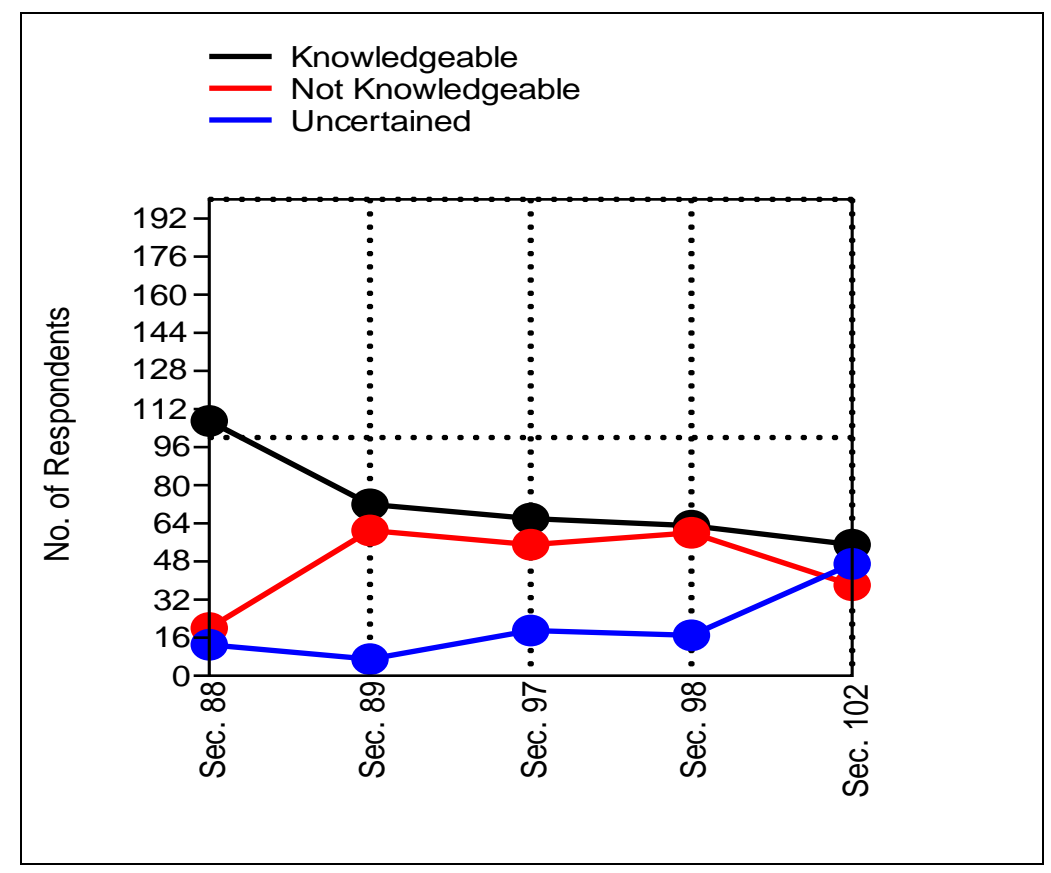

Figure 6: The respondents’ knowledge to the ichthyofaunal conservation measures.

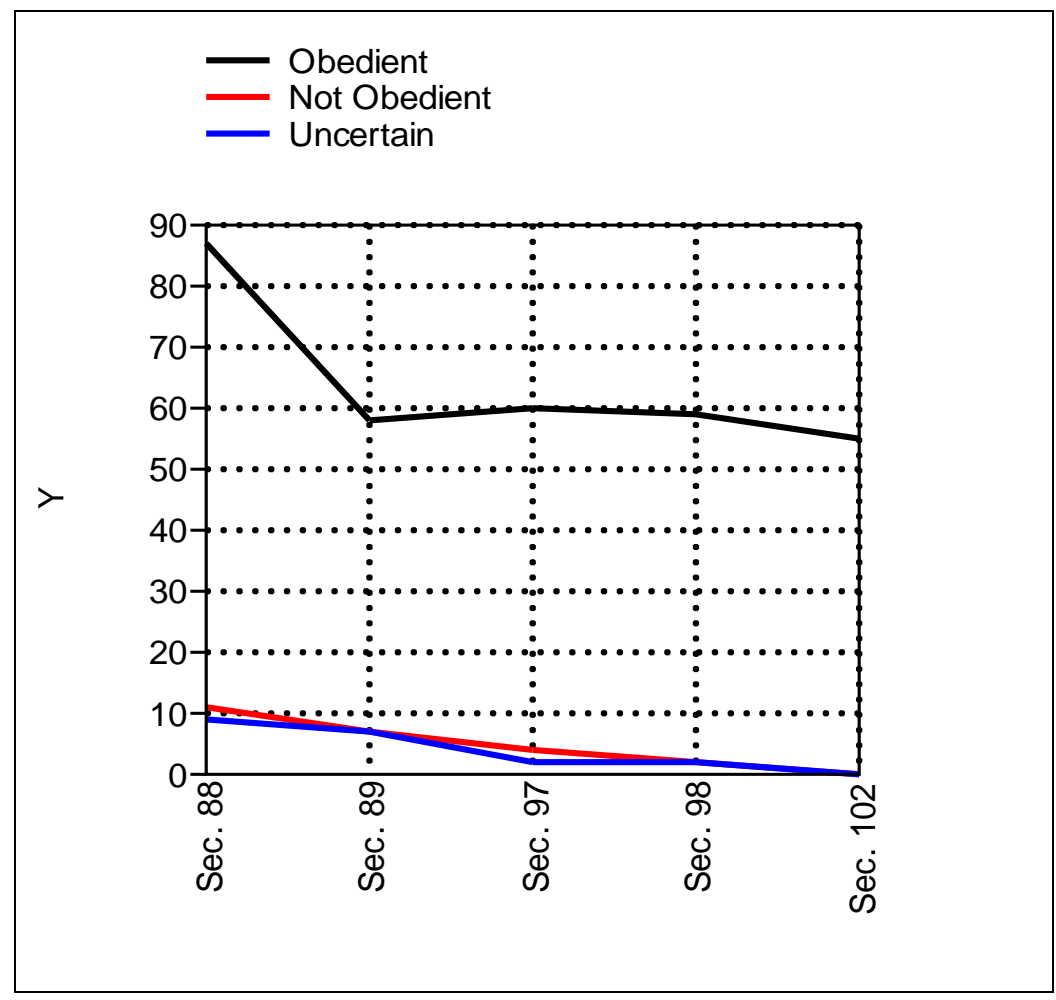

Figure 7: The respondents’ obedience to the ichthyofaunal conservation measures. 
Table 2a: The frequency distribution of the knowledge and obedience of the respondents towards the fisheries laws.

\begin{tabular}{|c|c|c|c|c|c|c|c|}
\hline \multirow{2}{*}{$\begin{array}{c}\text { Fisheries } \\
\text { Laws } \\
\text { RA 8550, } \\
\text { Ch. VI) }\end{array}$} & \multicolumn{7}{|c|}{ Knowledge } \\
\cline { 2 - 8 } & \multicolumn{2}{|c|}{ Knowledgeable } & \multicolumn{2}{|c|}{ Not knowledgeable } & \multicolumn{2}{|c|}{ Uncertain } & Total \\
\cline { 2 - 8 } & $\mathrm{F}$ & $\%$ & $\mathrm{~F}$ & $\%$ & $\mathrm{~F}$ & $\%$ & \\
\hline Section 88 & 107 & 76.43 & 20 & 14.29 & 13 & 9.29 & 140 \\
\hline Section 89 & 72 & 51.43 & 61 & 43.57 & 7 & 5.0 & 140 \\
\hline Section 97 & 66 & 47.14 & 55 & 39.29 & 19 & 13.57 & 140 \\
\hline Section 98 & 63 & 45.0 & 60 & 42.86 & 17 & 12.14 & 140 \\
\hline Section 102 & 55 & 39.29 & 38 & 27.14 & 47 & 33.57 & 140 \\
\hline
\end{tabular}

Table 2b: The frequency distribution of the knowledge and obedience.

\begin{tabular}{|l|c|c|c|c|c|c|c|}
\hline \multirow{2}{*}{$\begin{array}{c}\text { Fisheries } \\
\text { Laws } \\
\text { (RA 8550, } \\
\text { Ch. VI) }\end{array}$} & \multicolumn{2}{|c|}{ Obedient } & \multicolumn{2}{|c|}{ Not obedient } & \multicolumn{2}{c|}{ Uncertain } & Total \\
\cline { 2 - 8 } & $\mathrm{F}$ & $\%$ & $\mathrm{~F}$ & $\%$ & $\mathrm{~F}$ & $\%$ & \\
\hline Section 88 & 87 & 81.31 & 11 & 10.28 & 9 & 8.41 & 107 \\
\hline Section 89 & 58 & 80.56 & 7 & 9.72 & 7 & 9.72 & 72 \\
\hline Section 97 & 60 & 90.91 & 4 & 6.06 & 2 & 3.03 & 66 \\
\hline Section 98 & 59 & 93.65 & 2 & 3.17 & 2 & 3.17 & 63 \\
\hline Section 102 & 55 & 100 & 0 & 0 & 0 & 0 & 55 \\
\hline
\end{tabular}

Table 3a: Multiple Linear Regression between the respondents' socio-economic characteristics and their knowledge of various ichthyofaunal diversity conservation measures.

\begin{tabular}{|c|c|c|c|c|}
\hline \multirow{3}{*}{$\begin{array}{c}\text { Socio- } \\
\text { economic } \\
\text { characteristics }\end{array}$} & \multicolumn{4}{|c|}{ Ichthyofauna Diversity Conservation Measures (RA 8550, Ch. IV) } \\
\hline & \multicolumn{2}{|c|}{ Section 88} & \multicolumn{2}{|c|}{ Section 89} \\
\hline & Coeff. of correl. & $p$-value & Coeff. of correl. & $p$-value \\
\hline Age & 0.327 & $0.008 *$ & 0.025 & 0.828 \\
\hline No. of children & -0.125 & $0.032 *$ & -0.008 & 0.855 \\
\hline Education & 0.098 & 0.182 & -0.047 & 0.422 \\
\hline \multirow[t]{2}{*}{ Family Income } & 0.119 & 0.068 & 0.034 & 0.533 \\
\hline & \multicolumn{2}{|c|}{$\mathrm{R}^{2}=0.344$} & \multicolumn{2}{|c|}{$\mathrm{R}^{2}=0.010$} \\
\hline
\end{tabular}


Table 3b: Multiple Linear Regression between the respondents' socio-economic characteristics and their knowledge of various ichthyofaunal diversity conservation measures.

\begin{tabular}{|c|c|c|c|c|c|c|}
\hline \multirow{3}{*}{$\begin{array}{c}\text { Socio- } \\
\text { economic } \\
\text { characteristics }\end{array}$} & \multicolumn{6}{|c|}{ Ichthyofauna Diversity Conservation Measures (RA 8550, Ch. IV) } \\
\hline & \multicolumn{2}{|c|}{ Section 97} & \multicolumn{2}{|c|}{ Section 98} & \multicolumn{2}{|c|}{ Section 102} \\
\hline & $\begin{array}{l}\text { Coeff. of } \\
\text { Correlation }\end{array}$ & $p$-value & $\begin{array}{l}\text { Coeff. of } \\
\text { Correlation }\end{array}$ & $p$-value & $\begin{array}{l}\text { Coeff. of } \\
\text { Correlation }\end{array}$ & $p$-value \\
\hline Age & -0.037 & 0.785 & -0.063 & 0.636 & 0.197 & 0.238 \\
\hline $\begin{array}{l}\text { No. of } \\
\text { children }\end{array}$ & -0.009 & 0.857 & -0.019 & 0.696 & -0.002 & 0.973 \\
\hline $\begin{array}{r}\text { Educati } \\
\text { onal } \\
\text { Attainm } \\
\text { ent }\end{array}$ & 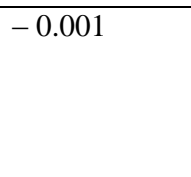 & 0.983 & -0.009 & 0.891 & -0.084 & 0.312 \\
\hline \multirow{2}{*}{$\begin{array}{l}\text { Family } \\
\text { Income }\end{array}$} & -0.074 & 0.252 & -0.070 & 0.265 & 0.056 & 0.477 \\
\hline & \multicolumn{2}{|c|}{$\mathrm{R}^{2}=0.013$} & \multicolumn{2}{|c|}{$R^{2}=0.014$} & \multicolumn{2}{|c|}{$\mathrm{R}^{2}=0.021$} \\
\hline
\end{tabular}

On the other hand, the obedience of the respondents to the stated fisheries laws does not show any relationship (Tab. 5). This means that their obedience is not dependent on their socio-economic characteristics. The proportion of influence of socio-economic characteristics on the respondents' obedience to the posed fisheries laws is very low, ranging from $1.4 \%$ (sec. 98) to $4.9 \%$ (sec. 88). As indicated above, the remaining large proportion of compliance is inferred to be due to the respondents' societal mores and religious beliefs, as the local dominant religion, Islam, demands compliance from its adherents. Furthermore, in Islam environmental conservation is a religious duty as well as social obligation, and not an optional matter. The exploitation of a particular natural resource is thus directly related to accountability and maintenance of the resource.

Table 4a: Multiple Linear Regression between the respondents' socio-economic characteristics and their obedience toVarious ichthyofaunal diversity conservation measures.

\begin{tabular}{|c|c|c|c|c|}
\hline \multirow{3}{*}{$\begin{array}{l}\text { Socio-economic } \\
\text { characteristics }\end{array}$} & \multicolumn{4}{|c|}{ Ichthyofauna Diversity Conservation Measures (RA 8550, Ch. IV) } \\
\hline & \multicolumn{2}{|c|}{ Section 88} & \multicolumn{2}{|c|}{ Section 89} \\
\hline & $\begin{array}{l}\text { Coeff. of } \\
\text { correlation }\end{array}$ & $\begin{array}{c}p- \\
\text { value }\end{array}$ & $\begin{array}{l}\text { Coeff. of } \\
\text { correlation }\end{array}$ & $\begin{array}{c}p- \\
\text { value }\end{array}$ \\
\hline Age & -0.249 & 0.065 & 0.349 & 0.059 \\
\hline No. of children & 0.059 & 0.250 & -0.040 & 0.554 \\
\hline $\begin{array}{l}\text { Educational } \\
\text { Attainment }\end{array}$ & -0.017 & 0.801 & 0.076 & 0.392 \\
\hline \multirow[t]{2}{*}{ Family Income } & 0.091 & 0.168 & 0.020 & 0.808 \\
\hline & \multicolumn{2}{|c|}{$\mathrm{R}^{2}=0.049$} & \multicolumn{2}{|c|}{$\mathrm{R}^{2}=0.061$} \\
\hline
\end{tabular}


Table 4b: Multiple Linear Regression between the respondents' socio-economic characteristics and their obedience toVarious ichthyofaunal diversity conservation measures.

\begin{tabular}{|l|l|l|l|l|l|l|}
\hline \multirow{2}{*}{$\begin{array}{l}\text { Socio- } \\
\text { economic } \\
\text { characteristics }\end{array}$} & \multicolumn{3}{|c|}{ Section 97} & \multicolumn{2}{c|}{ Section 98 } & \multicolumn{2}{c|}{ Section 102} \\
\cline { 2 - 7 } & $\begin{array}{l}\text { Coeff. of } \\
\text { correlation }\end{array}$ & $p$-value & $\begin{array}{l}\text { Coeff. of } \\
\text { correlation }\end{array}$ & $p$-value & $\begin{array}{l}\text { Coeff. of } \\
\text { correlation }\end{array}$ & $p$-value \\
\hline Age & -0.018 & 0.889 & -0.063 & 0.636 & -0.003 & 0.597 \\
\hline $\begin{array}{l}\text { No. of } \\
\text { children }\end{array}$ & -0.040 & 0.367 & -0.019 & 0.696 & 0.016 & 0.620 \\
\hline $\begin{array}{l}\text { Educational } \\
\text { Attainment }\end{array}$ & -0.003 & 0.969 & -0.009 & 0.891 & 0.055 & 0.175 \\
\hline $\begin{array}{l}\text { Family } \\
\text { Income }\end{array}$ & -0.016 & 0.779 & 0.070 & 0.265 & 0.025 & 0.506 \\
\cline { 2 - 8 } & \multicolumn{2}{|c|}{$\mathrm{R}^{2}=0.030$} & \multicolumn{2}{c|}{$\mathrm{R}^{2}=0.014$} & \multicolumn{2}{c|}{$\mathrm{R}^{2}=0.075$} \\
\hline
\end{tabular}

Table 5 shows the kinds of fish observed during the survey. Although these endemic cyprinids are classified as critically and vulnerably endangered, Puntius amarus, Puntius lindog and Puntius tumba are still being sold at the fish landing sites at $\$ 0.21$ apiece. There is a high demand for these fish species as they are favorite delicacies amongst the Meranao. The presence of Puntius lindog and Puntius tumba during the sampling reflects the findings of Ismail et al. (2014) in their study on the status of lake Lanao endemic cyprinids (Puntius species). While it is true that these endemic cyprinids are classified as critically endangered, the respondents were unaware of their status when asked whether they know that the species are vulnerable and critically endangered. In fact, most of them do not understand the concept of a rare or threatened organism.

\section{CONCLUSIONS}

Inasmuch as religious beliefs seem to be a major factor in the awareness of and obedience to ichthyofauna diversity conservation measures, a massive and intensified information drive regarding the law among fisher folks and other stakeholders should be conducted that would associate the law with their religious beliefs. This will result to a change in their values that will increase their sense of stewardship of the fisheries resources they have. From our findings, we would recommend that such an information drive should include the "imams" (religious teachers). All types of mass media should be included in the campaign. An extension worker should be assigned in the area so as to head this long-term information drive and to serve as liaison between the government and the local fisher folks in order for them to have strong community cooperation that will lead to the success of any ichthyofauna diversity conservation and sustainable fisheries projects. 
Table 5: List of various sampled ichthyofauna with their conservation status.

\begin{tabular}{|c|c|c|c|c|}
\hline Order & Family & $\begin{array}{l}\text { Name } \\
\text { of the } \\
\text { species }\end{array}$ & $\begin{array}{l}\text { Local } \\
\text { name }\end{array}$ & $\begin{array}{c}\text { IUCN } \\
\text { conservation } \\
\text { status* }\end{array}$ \\
\hline Perciformes & Eleotridae & $\begin{array}{l}\text { Hypseleotrisagilis } \\
\text { (Herre, 1927) }\end{array}$ & Katulong & LC \\
\hline Perciformes & Gobiidae & $\begin{array}{l}\text { Glossogobius guirus } \\
\text { (Hamilton, 1822) }\end{array}$ & Kadurog & LC \\
\hline Perciformes & Gobiidae & $\begin{array}{l}\text { Glossogobius celebius } \\
\text { (Valenciennes, 1837) }\end{array}$ & Kadurog & $\mathrm{DD}$ \\
\hline Perciformes & Cichlidae & $\begin{array}{l}\text { Oreochromis niloticus } \\
\text { (Linnaeus, 1758) }\end{array}$ & $\begin{array}{l}\text { Tilapia, } \\
\text { mampawi }\end{array}$ & NE \\
\hline Cypriniformes & Cyprinidae & $\begin{array}{l}\text { Puntius amarus } \\
\text { (Herre, 1924) }\end{array}$ & Pait & CR \\
\hline Perciformes & Channidae & $\begin{array}{l}\text { Ophicephalus striatus } \\
\text { (Bloch, 1793) }\end{array}$ & Aruan & LC \\
\hline Perciformes & Cichlidae & $\frac{\text { Oreochromis }}{\text { (Peters, } \frac{\text { mossambicus }}{1852)}}$ & $\begin{array}{l}\text { Tilapia, } \\
\text { Mampawi }\end{array}$ & NT \\
\hline Cypriniformes & Cyprinidae & $\begin{array}{l}\text { Cyprinus carpio } \\
\text { (Linnaeus, 1758) }\end{array}$ & Bongkaon & $\mathrm{VU}$ \\
\hline Siluriformes & Clariidae & $\begin{array}{l}\text { Clariasbatrachus } \\
\text { (Linnaeus, 1758) }\end{array}$ & Katipa & LC \\
\hline Siluriformes & Clariidae & $\begin{array}{l}\text { Clarias macrocephalus } \\
\text { (Günther, 1864) }\end{array}$ & Katipa & NT \\
\hline Perciformes & Anabantidae & $\begin{array}{l}\text { Anabas testudineus } \\
\text { (Bloch, 1792) }\end{array}$ & Puyo & $\mathrm{DD}$ \\
\hline Cypriniformes & Cyprinidae & $\begin{array}{l}\text { Puntius lindog } \\
\text { (Herre, 1924) }\end{array}$ & Lindog & VU \\
\hline Cypriniformes & Cyprinidae & $\begin{array}{c}\text { Puntius tumba } \\
\text { (Herre, 1924) }\end{array}$ & Tumba & $\mathrm{VU}$ \\
\hline Perciformes & Osphronemidae & $\begin{array}{l}\text { Trichopodus pectoralis } \\
\text { (Regan, 1910) }\end{array}$ & Gorami & LC \\
\hline
\end{tabular}

*Vulnerable (VU), Endangered (EN), Critically Endangered (CR), Near Threatened (NT), Extinct (EX) species, Data Deficient (DD), Not Evaluated (NE), Least Concern (LC).

ACKNOWLEDGEMENTS

The authors of the paper are indebted to the editors of Transylvanian Review of Systematical and Ecological Research. 


\section{REFERENCES}

1. Abubakar S. M., 2015 - Conservation and Islam, http://www.thefridaytimes.com /tft/conservation-and-islam/.

2. Adan W. R., 2009 - Fisheries Policies and Management in Panguil Bay, Journal of Environment and Aquatic Resources, 1, 1, 32-42.

3. Capistrano R. C. G., 2010 - Indigenous peoples, their livelihoods and fishery rights in Canada and the Philippines, The UN-Nippon Foundation Fellowship Programme, Division for Ocean Affairs And The Law Of The Sea, The United Nations, New York, USA.

4. Dalabajan D., 2005 - Fixing the Broken Net, Improving Enforcement of Laws Regulating Cyanide Fishing in the Calamianes Group Of Islands, Philippines, SPC Live Reef Fish Information Bulletin, 15.

5. Espectato L. N. and Serofia G. D., 2014 - Descriptive study of the fisheries registration and licensing system in selected municipalities of Panay Island, Philippines, Journal of Environmental Science and Management, 17, 2, 69-77.

6. Fabinyi M., 2007 - Illegal Fishing and Masculinity in the Philippines, A Look at the Calamianes Islands, Philippine Studies, 55, 4, 509.

7. Frey D. G., 1974 - A limnological reconnaissance of Lake Lanao, Mindanao Journal, 1, 1, 81101.

8. Jamil M. A., 1999 - A Study On Environmental Issues With Reference ToThe Qur'an And The Sunna, Imprimerie Al-Maarif Al-Jadida, Kingdom of Morocco.

9. Ismail G. B., Sampson D. B. and Noakes D. L. G., 2014 - The status of Lake Lanao endemic cyprinids (Puntius species) and their conservation, Environmental Biology Fish, 97, 425-434.

10. Katon B. M., Pomeroy R. S., Garces L. R. and Salamanca A. M., 1999 - Fisheries management of San Salvador Island, a shared responsibility, Society and Natural Resources, 12, 777-795.

11. Knudsen M., 2012 - Fishing families and cosmopolitans in conflict over land on a Philippine Island, Journal of Southeast Asian Studies, 43, 3.

12. McClellan K., 2010 - Coral degradation through destructive fishing practices, Retrieved from http://www.eoearth.org/view/article/151482.

13. Napata R. P., Espectato L. N. and Serofia G. D., 2014 - Descriptive study of the fisheries registration and licensing system in selected municipalities of Panay Island, Philippines, Journal of Environmental Science and Management, 17, 2, 69-77.

14. Palma M. A., 2006 - Analysis of the Adequacy of the Philippine legal, policy and institutional framework to combat illegal, unreported, and unregulated fishing, PhD Thesis, Center for Maritime Policy, University of Wollongong, Australia.

15. Systat, 2005 - Systat Software, Inc. California, United States of America. 